JOURNAL OF MECHANICAL ENGINEERING, MANUFACTURES, MATERIALS AND ENERGY

Doi: $10.31289 /$ jmemme.v5i2.4816

Available online http://ojs.uma.ac.id/index.php/jmemme

\title{
Analisis Pengaruh Temperatur Terhadap Sifat Termal dan Gugus Fungsi Proses Thermoforming Material Polivinil Klorida
}

\section{Analysis of The Effect of Temperature on Thermal Properties and Functions of Thermoforming Process of Polyvinyl Chloride Materials}

\author{
Budiarto Djono Siswanto1)*, Bayu Fajar Saputro'2), , Melya Dyanasari Sebayang3) \\ 1,2,3 Program Studi Teknik Mesin, Fakultas Teknik, Universitas Kristen Indonesia
}

Diterima: 23-01-2021 ; Disetujui: 02-09-2021 ; Diterbitkan: 30-12-2021

*Corresponding author: E-mail: budidamaz@gmail.com

\begin{abstract}
Abstrak
Membentuk plastik lembaran menjadi bermacam bentukan baru dan aplikasinya, plastik ini disesuaikan dengan desain yang kita inginkan dengan bantuan panas, tekanan dan cetakan. Tujuan dari penelitian ini adalah menentukan energi dan nilai panas yang dilepas material PVC dengan variasi suhu heating dan cooling pada forming unit, mengetahui pengaruh temperature proses PVC terhadap sifat termal dengan alat DSC dan mengetahui pengaruh temperature proses PVC terhadap gugus fungsi dengan alat FTIR . Hasil perhitungan menunjukkan panas yang dilepas oleh material A.1 sebesar 1,740 Watt dan A.2 sebesar 1,938 Watt. Energi yang diterima air pendingin pada menit ke 30 pada spesimen A.1 sebesar 5,571 Watt dan A.2 sebesar 14,857 Watt dengan kenaikan temperatur masing-masing sebesar $0,5^{\circ} \mathrm{C}$. Hasil uji DSC sample A.1 (cacat) dan A.2 (bagus) menunjukkan bahwa temperatur leleh dari keduanya hampir sama yaitu sekitar $78^{\circ} \mathrm{C}$ tetapi terdapat perbedaan pada $\mathrm{T}_{\mathrm{g}}$ (temperature glass) sebesar $0,013 \mathrm{~J} / \mathrm{g}^{\circ} \mathrm{C}$ lebih cepat spesimen uji A. $2115^{\circ} \mathrm{C}$ (Bagus). Hasil uji FTIR sample A.1 (cacat) dan A.2 (bagus) menunjukan adanya perbedaan panjang gelombang paling tinggi sampai dengan $8,4 \%$ pada nilai gelombang $3749.77 \mathrm{~cm}^{-1} \mathrm{dan}$ $3740.90 \mathrm{~cm}^{-1}$.
\end{abstract}

Kata Kunci : Thermoforming ; mesin UPS 1070 ; temperatur ; heating,; DSC dan FTIR

\begin{abstract}
Forming sheet plastic into various new shapes and applications, this plastic is adjusted to the design we want with the help of heat, pressure and molding. The purpose of this study was to determine the energy and heat value released by PVC material with variations in heating and cooling temperatures in the forming unit,to determine the effect of PVC process temperature on thermal properties with DSC tools and to determine the effect of PVC process temperature on functional groups using FTIR tools. The calculation results show that the heat released by the A.1 material is 1,740 Watt and A.2 is 1,938 Watt. The energy received by the cooling water in the 30th minute on specimen A.1 is 5.571 Watt and A.2 is 14,857 Watt with each temperature increase of $0.5^{\circ} \mathrm{C}$. The results of the DSC test samples A.1 (defective) and A.2 (good) show that the melting temperature of the two is almost the same, which is around $780 \mathrm{C}$ but there is a difference in $T_{g}$ (temperature glass) of $0.013 \mathrm{~J} / \mathrm{goC}$ faster than the A.2 test specimen $115{ }^{\circ} \mathrm{C}$ (Very nice). The results of the FTIR test samples A.1 (disabled), A.2 (good) showed the highest difference in wavelength up to $8.4 \%$ at the wave values of $3749.77 \mathrm{~cm}^{-1}$ and $3740.90 \mathrm{~cm}^{-1}$.
\end{abstract}

Keywords: Thermoforming; UPS 1070 engine; temperature; heating; DSC and FTIR 
Budiarto Djono Siswanto, Analisis pengaruh temperature terhadap sifat termal...

How to Cite: Siswanto, B.D., Analisis pengaruh temperature terhadap sifat termal dan gugus fungsi proses thermoforming material polivinil klorida, JMEMME (Journal of Mechanical Engineering, Manufactures, Materials and Energy), 5 (2): 134-150. 


\section{PENDAHULUAN}

Plastik didesain dengan banyak variasi properti yang dapat tahan terhadap panas, keras, ketahanan, derajat kekristalan, dan lain-lain. Plastik salah satu bentuk komposit yang mampu adaptasi saat diaplikasikan, karena komposisi yang umum dan beratnya yang ringan. Untuk itu plastik digunakan hampir di seluruh bidang industri, terutama industri rumah tangga. Plastik merupakan suatu polimer yang memiliki sifat - sifat yang flesibel. Plastik yang digunakan untuk kemasan memiliki berbagai kelebihan, diantaranya yaitu fleksibel, bentuk laminasi (aneka warna, tidak mudah rusak, dan harga yang relatif murah) dan transparan [1]. Proses thermoforming mencakup tiga tahap yaitu: memanaskan, menghisap (vacuum)untuk menjadikanbentuk sesuai dengan cetakan, mendinginkan plastik setelah dicetak. Bagian terpenting adalah pendinginan karena berpengaruh terhadap kualitas cetakan. Dengan sirkulasi pendinginan yang baik maka akan diperoleh hasil cetakan yang sempurna [2]. Ilustrasi proses thermoforming dapat dilihat pada Gambar 1.

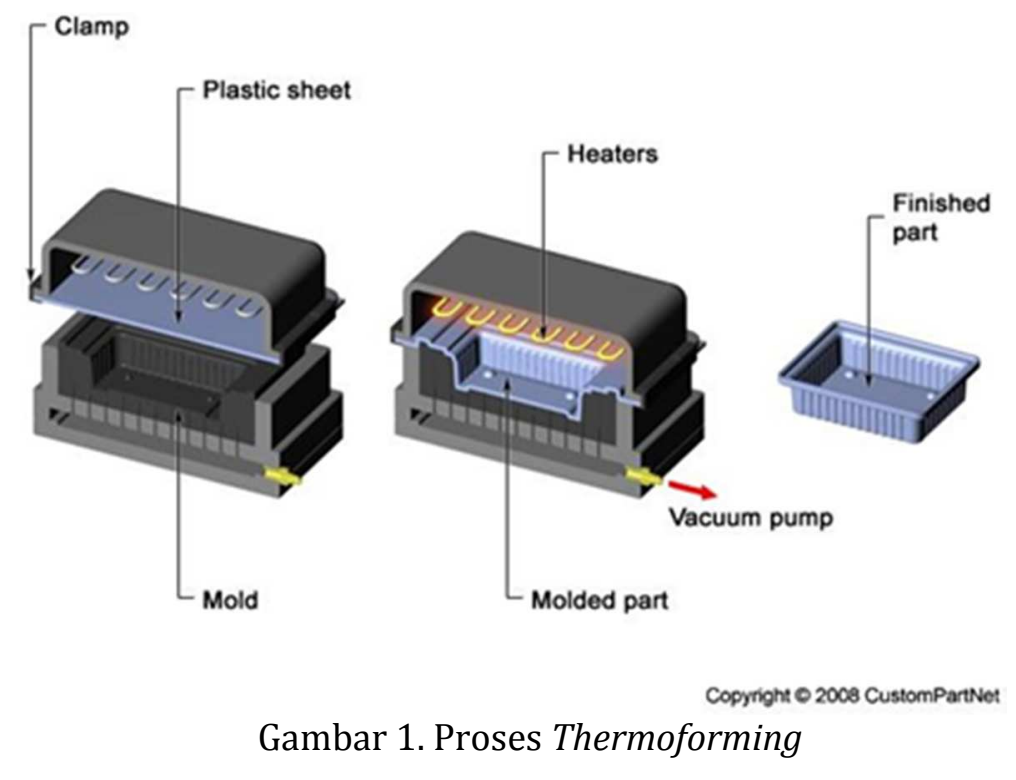

Thermoforming adalah proses mengambil selembar bahan plastik, memanaskannya sampai lentur, dan membentuknya menjadi bentuk tiga dimensi, kemudian memangkas dan menyelesaikannya menjadi produk yang dapat digunakan [3]. Thermoforming terdiri dari dua langkah utama: pemanasan dan pembentukan. Pemanasan biasanya dilakukan dengan pemanas listrik pancaran, yang terletak di satu atau kedua sisi lembaran plastik awal pada jarak kira-kira 125 mm (5 in.). Durasi siklus pemanasan yang diperlukan untuk cukup melunakkan lembaran tergantung pada polimer, ketebalan dan warnanya. Metode dimana langkah pembentukan dicapai dapat diklasifikasikan ke dalam tiga kategori dasar: 
Budiarto Djono Siswanto, Analisis pengaruh temperature terhadap sifat termal...

(1) thermoforming vakum, (2) thermoforming tekanan, dan (3) thermoforming mekanis. Dalam diskusi kami tentang metode ini, kami menggambarkan pembentukan stok lembaran; dalam industri pengemasan, sebagian besar operasi thermoforming dilakukan pada film tipis.

Metode paling awal adalah thermoforming vakum (disebut hanya pembentukan vakum ketika dikembangkan pada 1950-an), di mana tekanan negatif digunakan untuk menarik lembaran yang dipanaskan ke dalam rongga cetakan. Prosesnya dijelaskan di bawah ini dalam bentuk yang paling dasar. Lubang-lubang untuk menggambar ruang hampa di dalam cetakan berdiameter sekitar 0,8 $\mathrm{mm}(0,031 \mathrm{inci})$, jadi pengaruhnya pada permukaan plastik kecil.

Plastic Thermoforming adalah proses pembuatan plastik yang menerapkan gaya (vakum atau tekanan) untuk meregangkan selembar bahan termoplastik yang dipanaskan (thermo) di atas cetakan yang direkayasa untuk membuat bentuk atau bagian 3 dimensi (pembentukan) [4, 5]. Setelah dibentuk, bagian yang dibentuk kemudian dapat dipangkas dan diselesaikan sesuai spesifikasi untuk memenuhi kebutuhan pengguna akhir. Proses dan bahan termoplastik sangat serbaguna dan dapat digunakan untuk memproduksi suku cadang untuk berbagai aplikasi yang sangat luas.

Fleksibilitas dan efektivitas biaya proses thermoforming plastik menjadikannya pilihan ideal untuk beragam aplikasi industri. Bagian termoform plastik biasanya digunakan untuk menggantikan komponen lembaran logam fabrikasi dan juga menawarkan beberapa keunggulan unik dibandingkan suku cadang yang dibuat dengan proses manufaktur FRP (plastik yang diperkuat serat) dan RTM (resin transfer moulded) $[6,7]$. Desain baru atau konversi proses dari yang sudah ada, thermoforming komponen dengan Produktif Plastik dapat menjadi solusi ideal untuk aplikasi dan industri yang tak terhitung jumlahnya.

Penelitian ini di lakukan untuk menentukan energi panas yang dilepas material PVC dengan variasi suhu heating dan cooling pada forming unit, menentukan nilai panas yang diserap oleh air pendingin dengan variasi suhu heating dan forming pada mesin dan menentukan temperatur proses thermoforming material PVC $[8,9,10]$. Berdasarkan penelitian Bordonaro dkk (2008) dikatakan bahwa temperatur mold dan sheet memilik pengaruh yang tinggi terhadap kualitas produk [11]. Permasalahan umum yang sering terjadi pada industri injeksi plastik adalah adanya penyusutan pada produk hasil proses 
injeksi. Dalam proses injection molding terdapat banyak parameter yang dapat mempengaruhi hasil injeksi $[12,13]$. Ditemukan beberapa permasalahan pada proses thermoforming yaitu hasil poket tidak sempurna atau dangkal seperti diperlihatkan pada gambar 2.
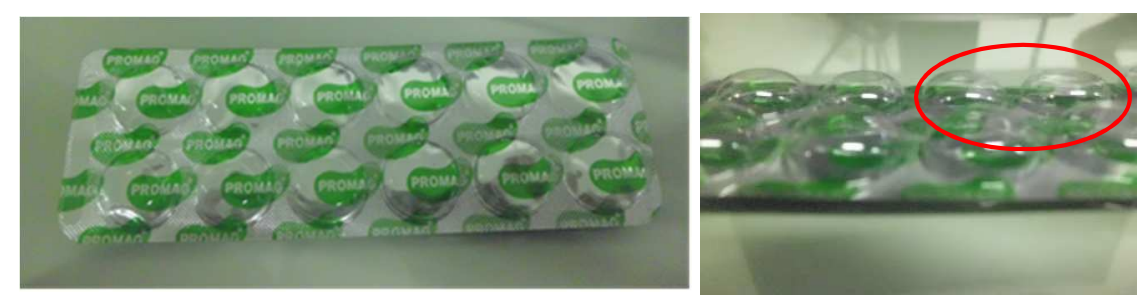

Gambar 2. Pocke blister: (a) poket sempurna (b) cacat

Tujuan Penelitian ini adalah menentukan energi dan nilai panas yang dilepas material PVC dengan variasi suhu heating dan cooling pada forming unit, mengetahui pengaruh temperature proses PVC terhadap sifat termal dengan alat DSC (Differential Scanning Calorimetry), dan mengetahui pengaruh temperature proses PVC terhadap gugus fungsi dengan alat FTIR (Fourier-transform Infrared Spectroscopy).

\section{METODE PENELITIAN}

Diagram alir penelitian ini diperlihatkan pada gambar 3. Dalam penelitian ini dimulai dengan perhitungan teoritis penelitian teknikal data serta analisis perpindahan panasnya, setelah itu mulai pengujian dengan proses thermoforming di mesin UPS1070 dan pengukuran dimensi specimen uji, setelah selesai pengukuran kita lakukan pengujian dengan alat DSC di BPPT serpong dan pengujian FTIR di Balai laboratorium Bea dan Cukai.

\section{Data analisis perpindahan aliran panas}

Data analisis meliputi data dimensional dari komponen yang akan digunakan dalam penelitian dan material lain yang terkait. Berikut data dari air pendingin, material PVC, Specifikasi forming unit hingga pamameter settingan mesin untuk menentukan besar energi pada mesin UPS 1070. 
Budiarto Djono Siswanto, Analisis pengaruh temperature terhadap sifat termal...

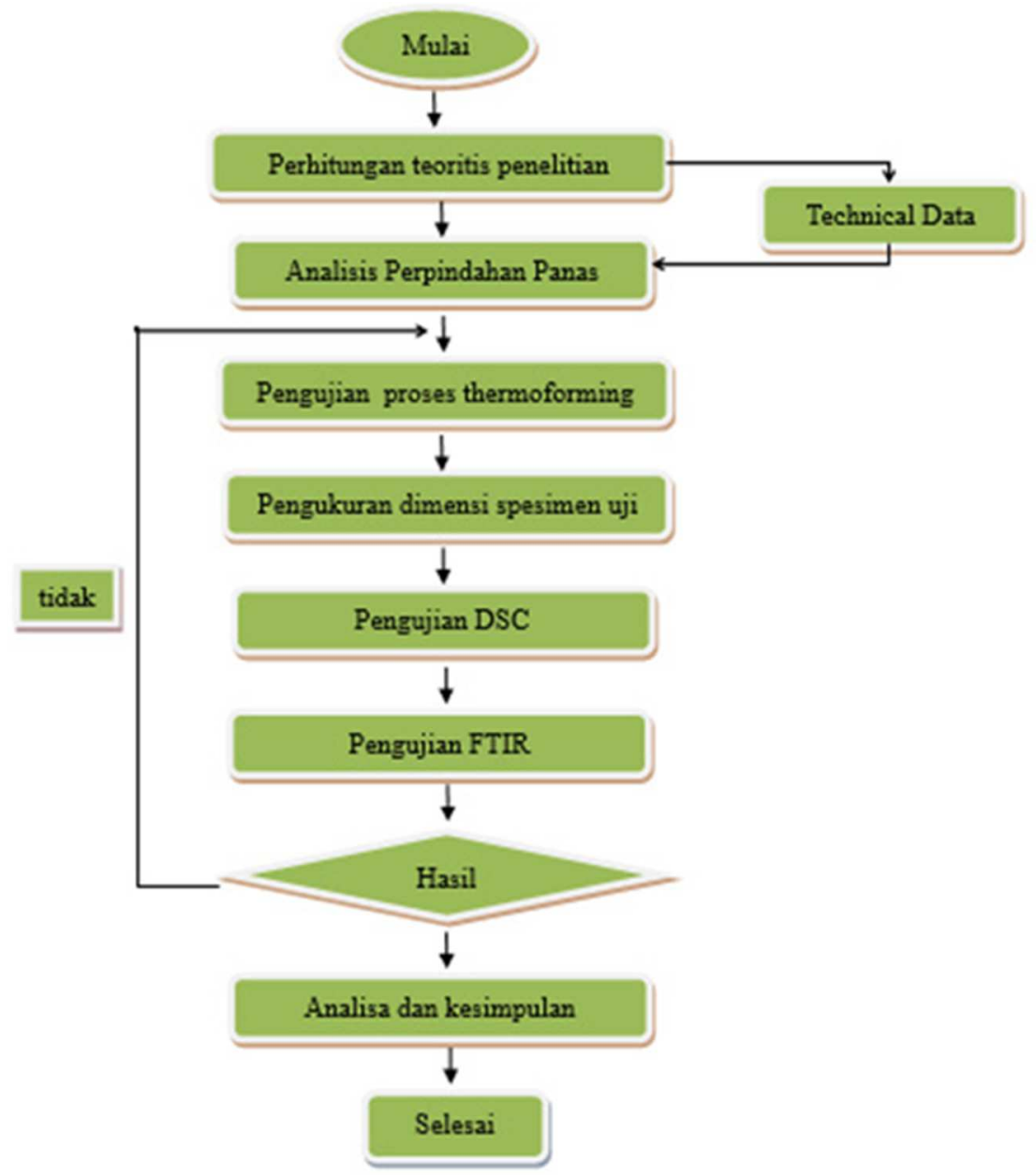

Gambar 3. Diagram alir penelitian

Data dari air pendingin yang maliputi spesifikasi saluran pendingin diperlihatkan pada tabel 1.

Tabel 1. Karakteristik Air pendingin (cooling)

\begin{tabular}{ll}
\hline Karakteristik & Nilai Besaran \\
\hline Debit air pendingin $\left(\mathrm{Q}_{\mathrm{h}}\right)$ & $0,00016 \mathrm{~m}^{3} / \mathrm{s}$ \\
Dynamic viscisity & $0,00000152 \mathrm{Kg}$ 'm.s \\
Media pendingin & Air \\
Density $(\rho)$ & $1000 \mathrm{Kg} / \mathrm{m}^{3}$ \\
Panjang saluran pendingin & $5 \mathrm{~m}$ \\
Diameter saluran pendingin & $0,008 \mathrm{~m}$ \\
Tebal forming unit & $0,05 \mathrm{~m}$ \\
\hline
\end{tabular}


Pada pengujian tersebut menggunakan material PVC dengan spesifikasi seperti diperlihatkan pada tabel 2.

Tabel 2. Sifat-sifat fisik material Polivinnil Clorida

\begin{tabular}{ll}
\hline Sifat-sifat Fisik & Nilai Besaran \\
\hline Tebal bahan PVC & $0,75 \mathrm{~mm}$ \\
Density $(\rho)$ & $1630 \mathrm{Kg} / \mathrm{m}^{3} \mathrm{~K}$ \\
Konduktifitas termal $(\mathrm{K})$ & $0,13 \mathrm{~W} / \mathrm{m} \mathrm{K}$ \\
Panas jenis $(\mathrm{Cp})$ & $1,259 \mathrm{~J} / \mathrm{kg} \mathrm{K}$ \\
Volume plastik & $4,819.10^{-8} \mathrm{~m}^{3}$ \\
Massa plastik & $15,709.10^{-3} \mathrm{Kg} / \mathrm{s}$ \\
\hline
\end{tabular}

Spesifikasi forming unit hingga pamameter settingan mesin untuk menentukan besar energy mesin UPS1070 diperlihatkan pada tabel 3.

Tabel 3. Spesifikasi forming unit mesin

\begin{tabular}{ll}
\hline Parameter & Jenis / Nilai \\
\hline Bahan material & Alumunium \\
Panjang forming & $230 \mathrm{~mm}>0,23 \mathrm{~m}$ \\
Lebar forming & $210 \mathrm{~mm}>0,21 \mathrm{~m}$ \\
Diameter dalam forming & $5 \mathrm{~mm}>0,05 \mathrm{~m}$ \\
Thermal conductivity & $237 \mathrm{~W} / \mathrm{m}^{\circ} \mathrm{k}$ \\
\hline
\end{tabular}

\section{Persiapan lembar Polyvinnil Clorida}

Persiapan dimulai dengan menentukan jenis plastik yang akan digunakan yaitu lembar PVC ukuran lebar $238 \mathrm{~mm}$ dan ketebalan 0,75 $\mathrm{mm}$. Dimensi didapat dari spesifikasi pembelian material PVC Film pada tabel 4.

\begin{tabular}{|c|c|c|c|c|c|c|c|c|}
\hline $\begin{array}{l}\text { Batch } \\
0088918200\end{array}$ & \multicolumn{4}{|c|}{$\begin{array}{l}\text { Materian description OP-M176/01- } \\
\text { 51/9000-100_0-222-250-238 }\end{array}$} & $\begin{array}{l}\text { Major } \\
51 / 9000\end{array}$ & $\begin{array}{l}\text { Thickn } \\
250\end{array}$ & $\begin{array}{l}\text { Material } \\
2250\end{array}$ & Pcs 1 \\
\hline Cust batch & \multicolumn{2}{|c|}{$\begin{array}{l}\text { Cust order no } \\
\text { P122113-19 }\end{array}$} & \multicolumn{2}{|c|}{$\begin{array}{l}\text { Cust material } \\
231558 \_880\end{array}$} & winding & $\begin{array}{l}\text { Core } 76 \\
\mathrm{~mm}\end{array}$ & \multicolumn{2}{|c|}{$\begin{array}{l}\text { Orc/cut/pos/obj } \\
602426460 / 1 / \mathrm{E} / 23\end{array}$} \\
\hline $\begin{array}{l}\text { Order } \\
1595596 / 10\end{array}$ & $\begin{array}{l}\text { Length } \\
800 \mathrm{~m}\end{array}$ & $\begin{array}{l}\text { Width } \\
238 \\
\mathrm{~mm}\end{array}$ & $\begin{array}{l}\text { Weight } \\
64,2 \mathrm{~kg}\end{array}$ & $\begin{array}{l}\text { Splices } \\
0\end{array}$ & \multicolumn{2}{|c|}{$\begin{array}{l}\text { Recom processing by } \\
06.11 .2020\end{array}$} & \multicolumn{2}{|c|}{ Prod 07.11.2019 } \\
\hline
\end{tabular}

Tabel 4. Spesifikasi Material PVC 
Budiarto Djono Siswanto, Analisis pengaruh temperature terhadap sifat termal...

\section{Proses pembuatan pocket}

Proses forming pembuatan spesimen uji dilakukan pada mesin UPS 1070. Tahapan proses pembuatannya adalah menyiapkan material plastik yaitu (PVC), melakukan setting temperatur forming pada $17^{\circ} \mathrm{C}$, melakukan setting temperatur dengan 3 variasi yang berbeda yaitu : $105^{\circ} \mathrm{C}, 115^{\circ} \mathrm{C}$, menjalankan mesin selama 30 menit kemudian ambil 1 produk sebagai spesimen uji, dan memberi penanda pada spesimen sesuai dengan temperatur forming dan heating.

\section{Proses pengukuran pocket}

Pengukuran spesimen uji menggunakan digital caliper (gambar 4) untuk memperoleh hasil pengukuran akurat. Pengukuran dimensi dilakukan pada tebal dan diameter sesuai dengan standart ukuran dimensi.

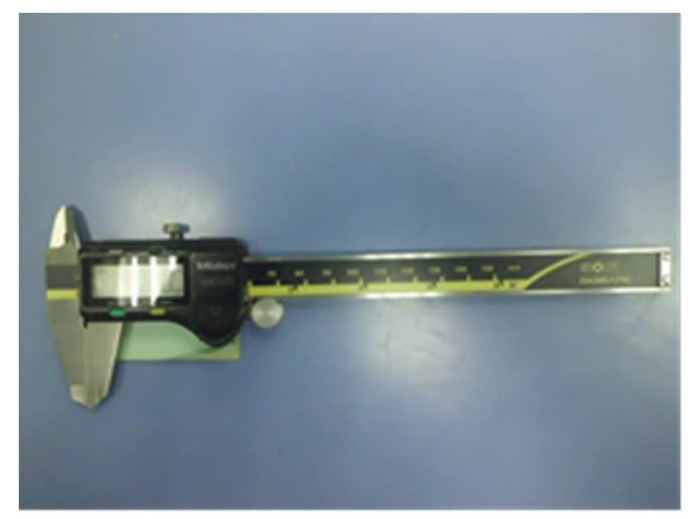

Gambar 4. Digital Caliper

Pengukuran tebal pocket dilakukan pada 1 titik dan diameter dilakukan pada 3 titik. Kemudian diambil rata-rata dengan toleransi ukuran $\pm 0,2 \mathrm{~mm}$. Pengukuran pada dimensi tebal, dan diameter hasil pocket diperlihatkan pada gambar 5 .

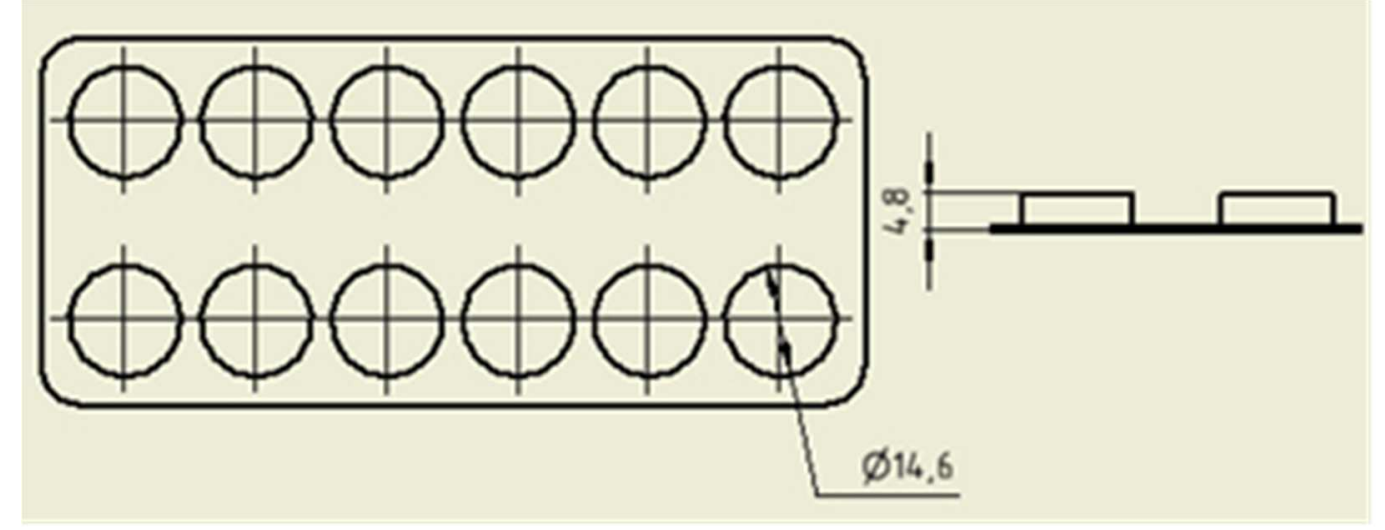

Gambar 5. Standar pengukuran pocket 


\section{Pengujian dengan alat uji Differential Scanning Calorimetry}

Analisis termal dalam pengertian luas adalah pengukuran sifat kimia fisika bahan sebagai fungsi suhu. Penetapan dengan metode ini dapat memberikan informasi pada kesempurnaan kristal, polimorfisma, titik lebur, sublimasi, transisi kaca, interaksi padatpadat dan kemurnian [6].

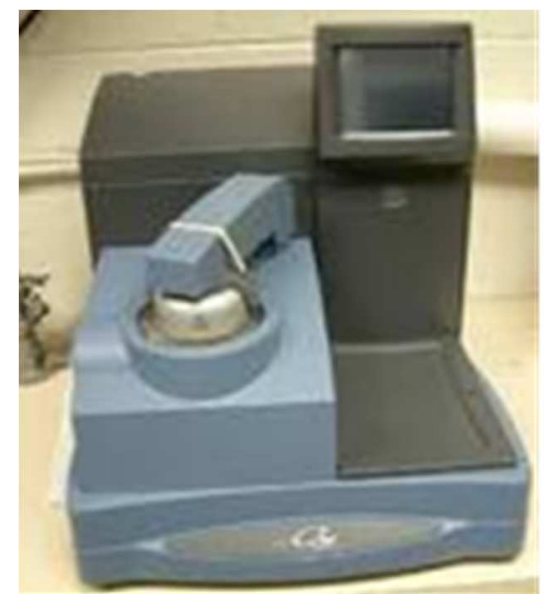

Gambar 6. Alat Uji DSC Diferensia

Pengujian dengan alat uji spektrum inframerah

Spektrum inframerah dihasilkan dari pentrasmisian cahaya yang melewati sampel. Pengukuran dilakukan dengan mengukur intensitas cahaya dengan detektor dan dibandingkan dengan intensitas tanpa sampel sebagai fungsi panjang gelombang. Spektrum inframerah yang diperoleh kemudian diplot sebagai intensitas fungsi energi, panjang gelombang $(\mu \mathrm{m})$ atau bilangan gelombang $\left(\mathrm{cm}^{-1}\right)$ [14]. Alat uji untuk megukur Spektrum inframerah diperlihatkan pada gambar 7.

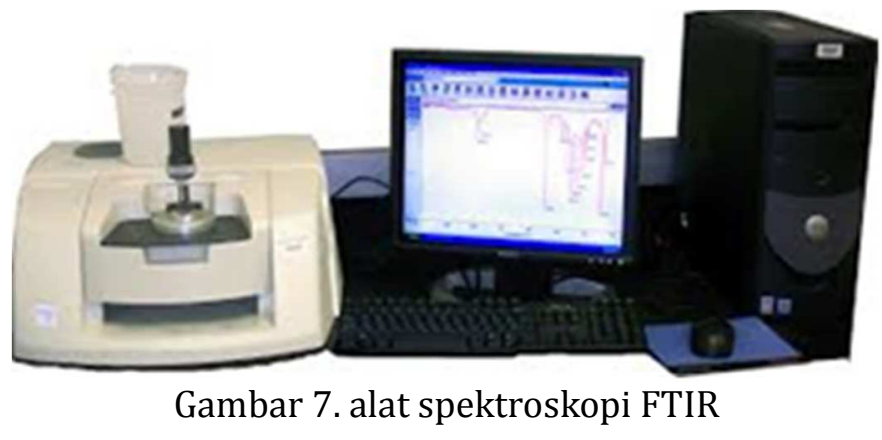

\section{HASIL DAN PEMBAHASAN}

Setelah diketahui besaran dari masing- masing dimensi forming unit dan spesifikasi dari plastik dapat dihitung besarnya volume plastik ketika masuk dalam forming unit. Hasil perhitungan tersebut diperlihatkan pada tabel 5. 
Budiarto Djono Siswanto, Analisis pengaruh temperature terhadap sifat termal...

Tabel 5. Data energi ya dilepas plastik

\begin{tabular}{rcccccc}
\hline No & $\begin{array}{c}\text { Spesimen } \\
\mathrm{Uji}\end{array}$ & $\begin{array}{c}\text { Temperatur } \\
\text { Forming }\left({ }^{\circ} \mathrm{C}\right)\end{array}$ & $\begin{array}{c}\text { Temperatur } \\
\text { Heating }\left({ }^{\circ} \mathrm{C}\right)\end{array}$ & $\begin{array}{c}\text { Massa PVC } \\
(\mathbf{k g} / \mathbf{s})\end{array}$ & $\begin{array}{c}\mathbf{C P}_{\text {plastic }} \\
\left(\mathbf{J} / \mathbf{k g}{ }^{\circ} \mathrm{C}\right)\end{array}$ & Q $_{\text {plastic }}$ (Watt) \\
\hline 1 & A.1 & \multirow{2}{*}{17} & 105 & 15,709 & 1,259 & 1314,28 \\
2 & A.2 & & 115 & & & 1613,03 \\
\hline
\end{tabular}

Energi yang diserap cetakan mesin memiliki 1 cetakan maka nilai Qplastik sama dengan energi yang diterima oleh cetakan. Besarnya energi yang diserapkan diperlihatkan pada tabel 6.

Tabel 6. Energi yang diserap cetakan

\begin{tabular}{ccc}
\hline No & Spesimen Uji & $\boldsymbol{Q}_{\text {plastik }}($ Watt $)=Q_{\text {cetakan }}$ (Watt) \\
\hline 1 & A.1 & 1,740 \\
2 & A.2 & 1,938 \\
\hline
\end{tabular}

Analisis total perpidahan panas yang terjadi pada cetakan dari forming unit (Qtot) secara konduksi analisa total perpindahan panasnya diperlihatkan pada tabel 7.

Tabel 7. Analisis total perpidahan panas cetakan

\begin{tabular}{ccc}
\hline No & Spesimen uji & Analisis total perpindahan panas (Watt) \\
\hline 1 & A.1 & 24,451 \\
2 & A.2 & 65,204 \\
\hline
\end{tabular}

Perpindahan panas air pendingin adalah energi yang diterima oleh air pedingin. Hasil perhitungan energi tersebut diperlihatkan pada tabel 8.

Tabel 8. Perpindahan panas air pendingin

\begin{tabular}{ccccc}
\hline No & Spesimen uji & $\begin{array}{c}\text { Setting Temperatur } \\
\text { Forming }\left({ }^{\circ} \mathrm{C}\right)\end{array}$ & $\begin{array}{c}\text { Setting Temperatur } \\
\text { Heating }\left({ }^{\circ} \mathrm{C}\right)\end{array}$ & $\begin{array}{c}\text { Temperatur air } \\
\text { setelah cetakan } \\
\left({ }^{\circ} \mathrm{C}\right)\end{array}$ \\
\hline 1 & A.1 & 17 & 105 & 17,3 \\
2 & A.2 & & 115 & 17,8 \\
\hline
\end{tabular}


Hasil Pengukuran Spesimen Uji menggunakan digital caliper pada unit kerja kalibrasi. Pengukuran tinggi dan lebar pocket spesimen dilakukan di 3 titik kemudin diambil ratarata. Hasilnya diperlihatkan pada tabel 9.

Tabel 9. Hasil Pengukuran Spesimen Uji

\begin{tabular}{ccccc}
\hline \multirow{2}{*}{ Spesimen Uji } & \multicolumn{2}{c}{ Standart Pengukuran $(\mathbf{m m})$} & \multicolumn{2}{c}{ Hasil Pengukuran $(\mathrm{mm})$} \\
& Tebal & Diameter Pocket & Tebal & Diameter Pocket \\
\hline A.1 (Cacat) & 4.8 & 14.8 & 4.7 & 14.6 \\
A.2 (Bagus) & & & 4.8 & 14.8 \\
\hline
\end{tabular}

Dari data diatas bentuk pocket yang tidak sempurna disebabkan karena material PVC sheet belum mencapai titik temperatur optimal pembentukan. Hal ini berpengaruh pada keuletan material PVC sheet untuk proses forming.

\section{Hasil Pengujian sifat termal spesimen}

Analisis ini menggunakan dua wadah sampel dan pembanding yang identik dan umumnya terbuat dari aluminium. Setelah proses pengujian, spesimen diamati sifat termal. Data hasil pengujian diperlihatkan pada gambar 8.

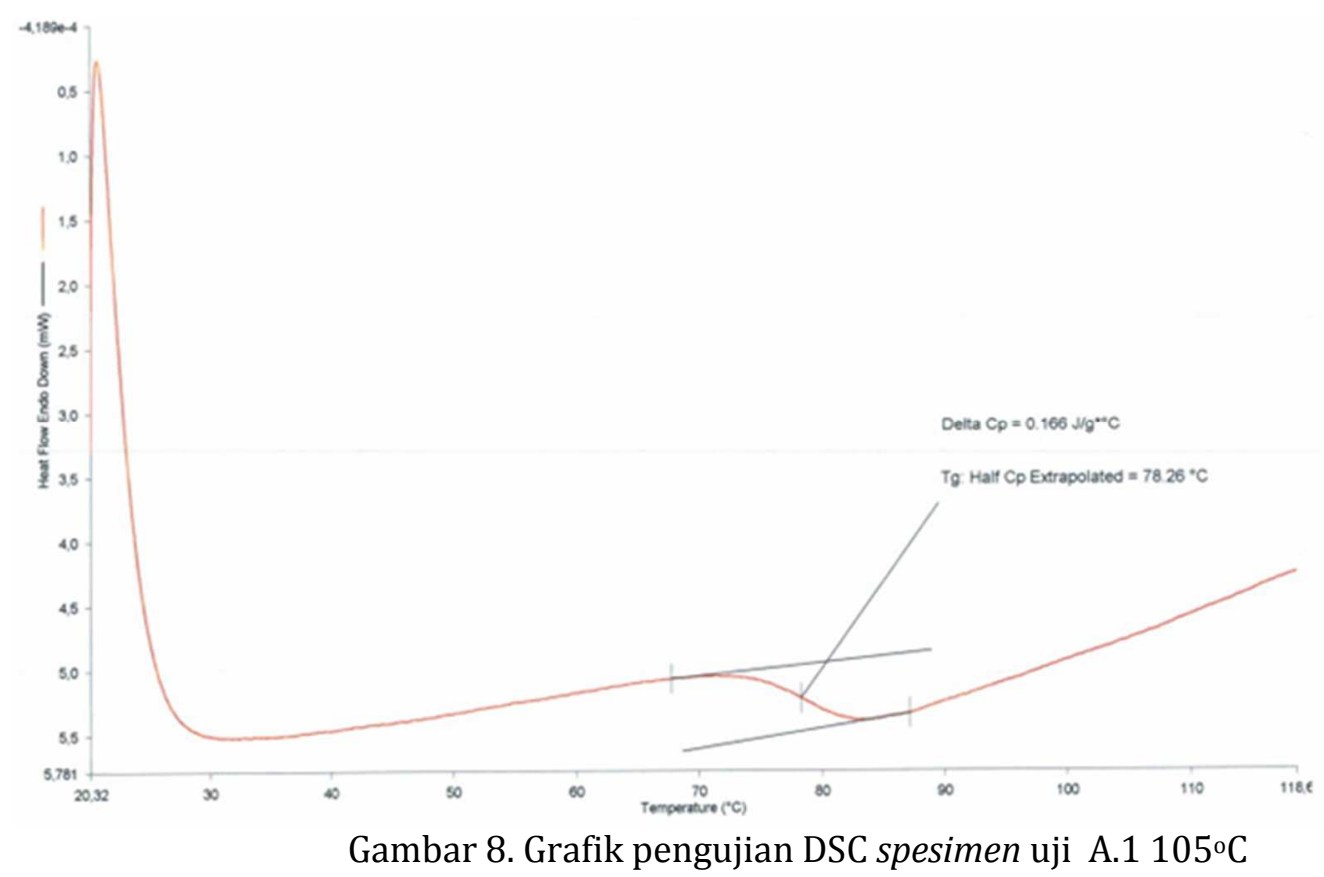


Berdasarkan grafik pengujian DSC spesimen uji A.1 $105^{\circ} \mathrm{C}$ menunjukkan termogram untuk spesimen cacat menunjukkan adanya sebuah puncak yaitu pada suhu $78,26^{\circ} \mathrm{C}$ dengan entalphi sebesar $0,166 \mathrm{~J} / \mathrm{g}^{\circ} \mathrm{C}$. Dimana suhu tersebut diidentifikasikan sebagai temperatur leleh spesimen cacat. Sedangkan entalphi adalah energi yang dibutuhkan untuk mengubah spesimen cacat dari wujud padat menjadi cair. Reaksi yang terjadi adalah reaksi eksotermal yang ditunjukkan dengan bentuk yang landai kebawah seperti diperlihatkan pada gambar 9.

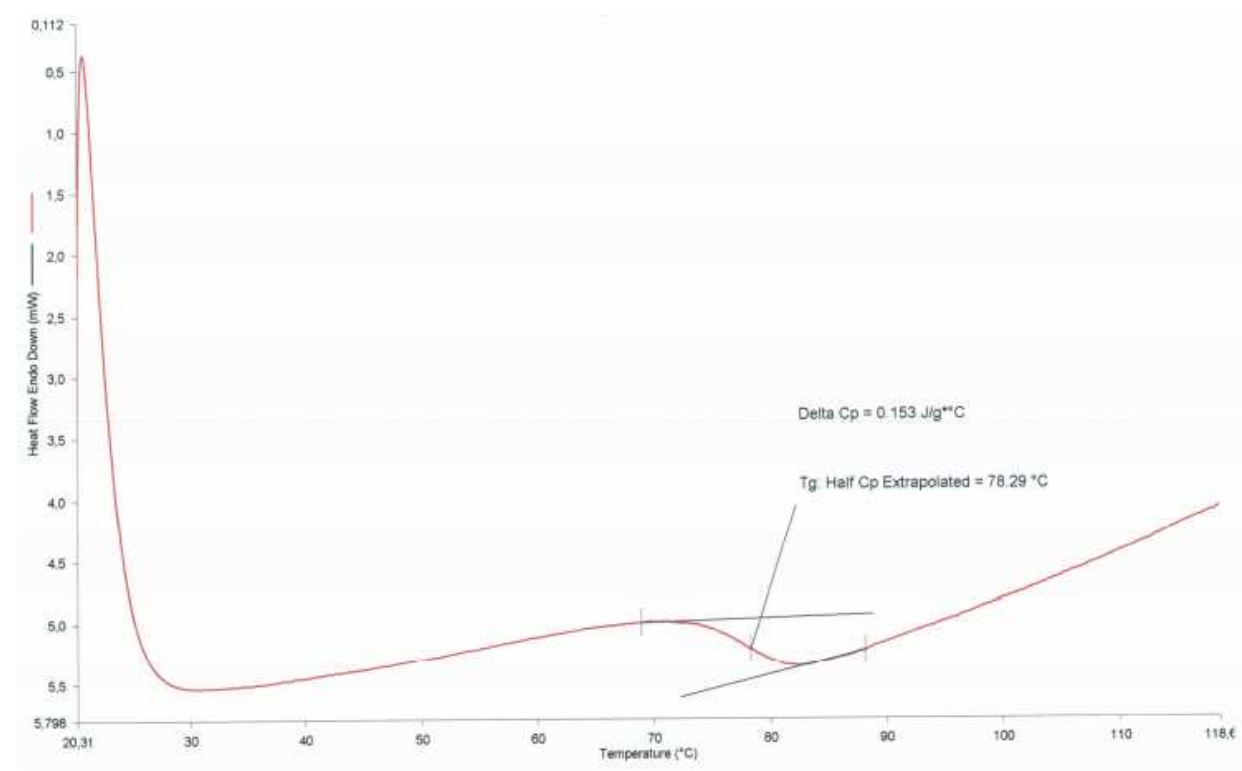

Gambar 9. Grafik pengujian DSC spesimen uji A.1 $115^{\circ} \mathrm{C}$

Berdasarkan grafik pengujian DSC spesimen uji A. $2115^{\circ} \mathrm{C}$ menunjukkan termogram untuk spesimen bagus menunjukkan adanya sebuah puncak yaitu pada suhu $78,29^{\circ} \mathrm{C}$ dengan entalphi sebesar $0,153 \mathrm{~J} / \mathrm{g}^{\circ} \mathrm{C}$. Dimana suhu tersebut diidentifikasikan sebagai temperatur leleh spesimen bagus sedangkan entalphi adalah energi yang dibutuhkan untuk mengubah spesimen bagus dari wujud padat menjadi leleh. Dan reaksi yang terjadi adalah reaksi eksotermal yang ditunjukkan dengan bentuk yang landai kebawah. Berdasarkan study Todingbua dkk (2018) suhu transisi gelas (Tg) tidak bisa dipastikan karena memiliki tingkat kristalinitas yang tingggi [15]. Untuk oligomer, Tg diamati di 86 $\mathrm{C}$ bersama dengan Tm, menandakan adanya sejumlah besar fase kristal. Berdasarkan kedua grafik termogram DSC diatas menunjukkan bahwa temperatur leleh dari keduanya hampir sama yaitu sekitar $78^{\circ} \mathrm{C}$ tetapi terdapat perbedaan pada $\mathrm{T}_{\mathrm{g}}$ (temperature glass) sebesar $0,013 \mathrm{~J} / \mathrm{g}^{\circ} \mathrm{C}$ lebih cepat spesimen uji A. $2115^{\circ} \mathrm{C}$. 


\section{Hasil Pengujian spectrum inframerah}

Data hasil pengujian disajikan dalam bentuk gugus fungsi seperti diperlihatkan pada gambar 10 dan 11.

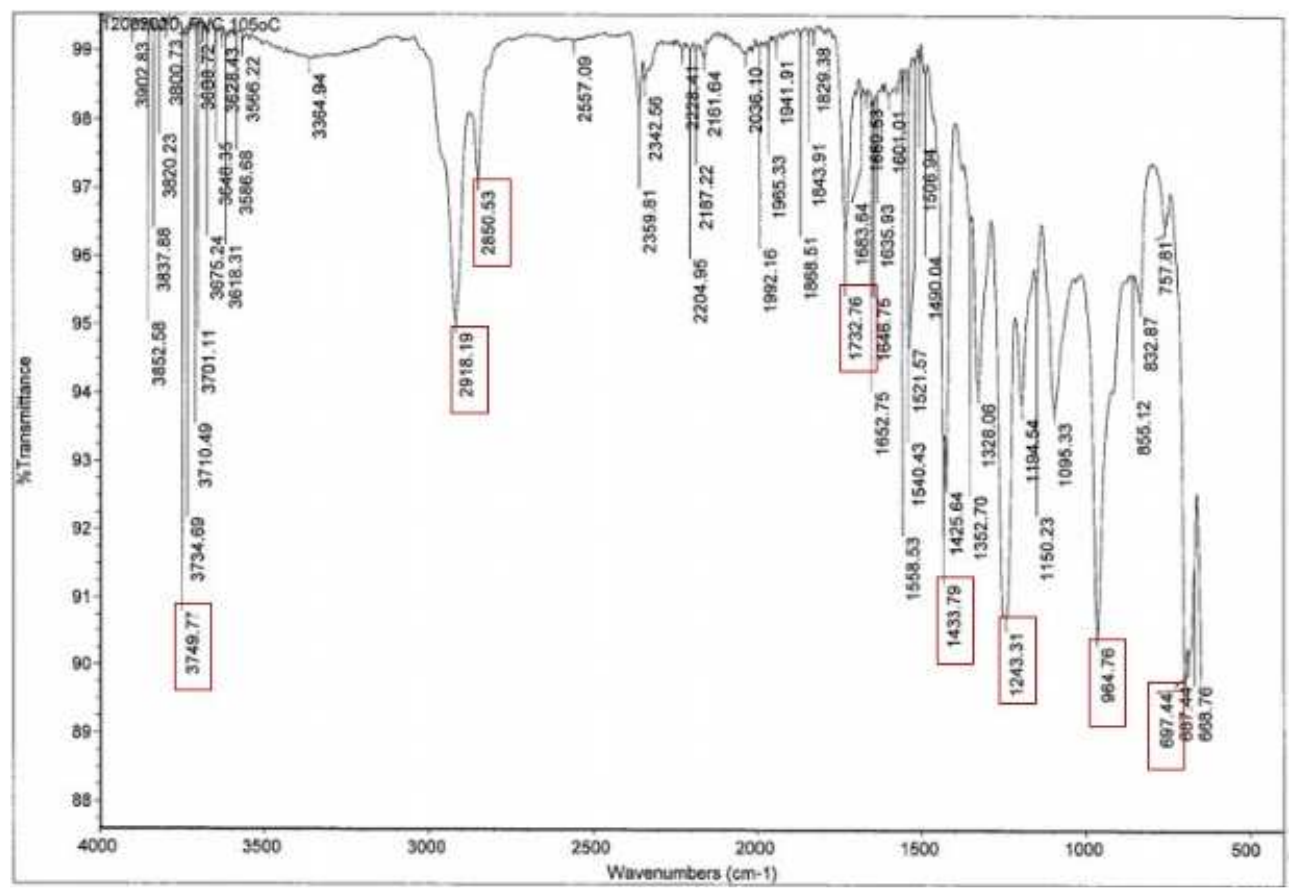

Gambar 10. Data hasil pengujian FTIR spesimen uji A.1 $105^{\circ} \mathrm{C}$

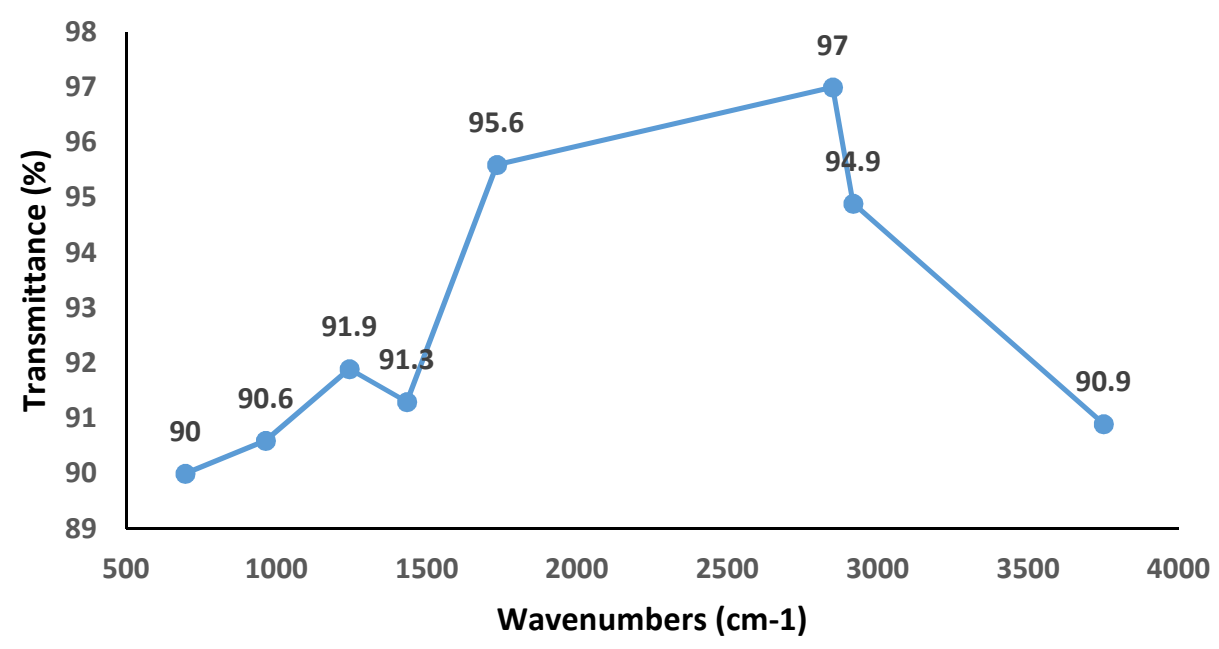

Gambar 11. Grafik panjang gelombang $105^{\circ} \mathrm{C}$

Berdasarkan Gambar 12 dan 13, grafik intensitas serapan gugus fungsi panjang gelombang pada material PVC menunjukkan panjang gelombang pada sample cacat dengan nilai gelombang $697.44 \mathrm{~cm}^{-1}$ - $1243.31 \mathrm{~cm}^{-1}$ mengalami kenaikan panjang gelombang, mulai penurunan panjang gelombang pada nilai gelombang $1433.79 \mathrm{~cm}^{-1}$ naik 
Budiarto Djono Siswanto, Analisis pengaruh temperature terhadap sifat termal...

lagi pada nilai gelombang $1732.76^{-1}-2850.53 \mathrm{~cm}^{-1}$ dan mulai turun lagi pada nilai. $2918.19 \mathrm{~cm}^{-1}-3749.77 \mathrm{~cm}^{-1}$.

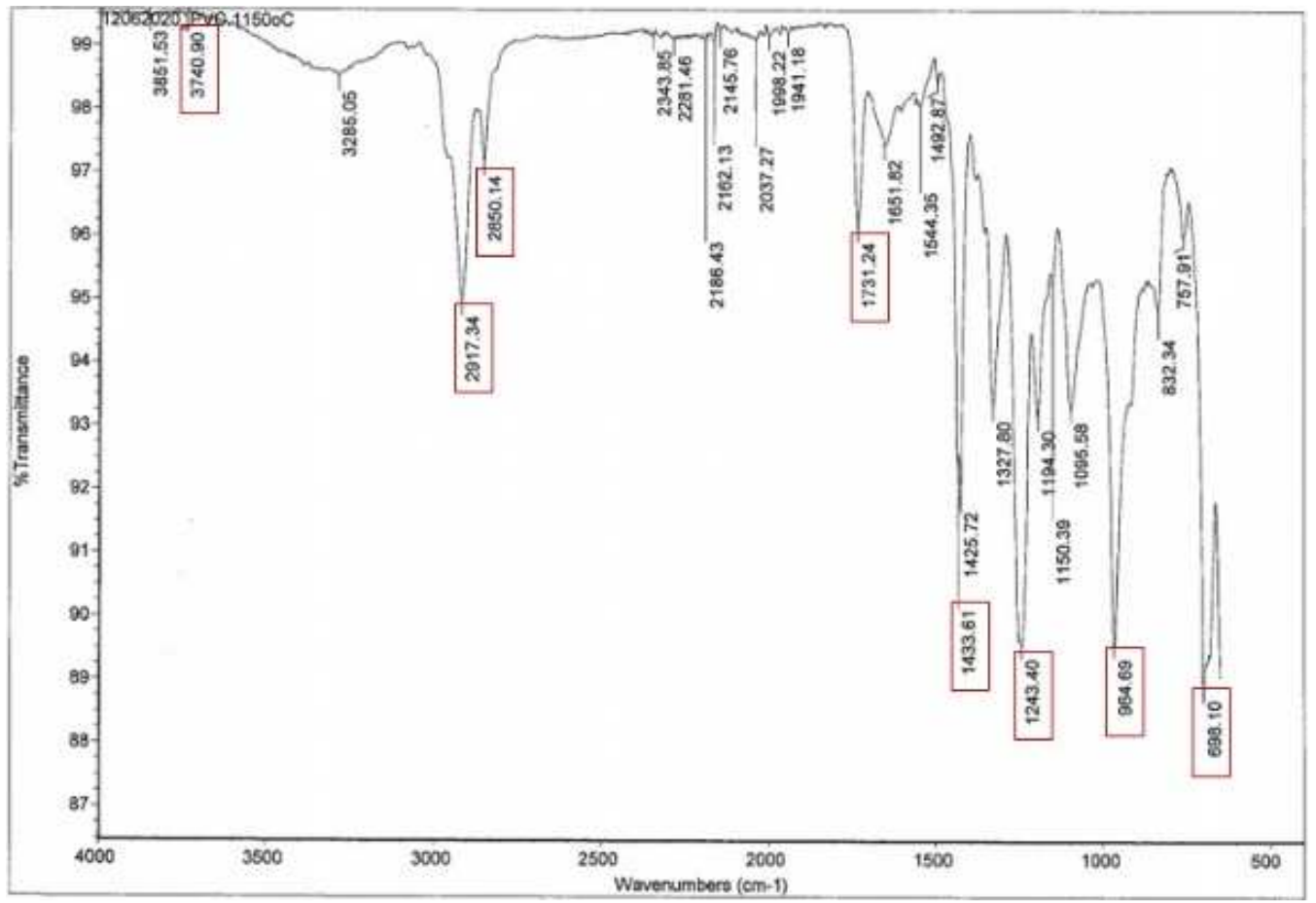

Gambar 12. Data hasil pengujian FTIR spesimen uji A.2 $115^{\circ} \mathrm{C}$

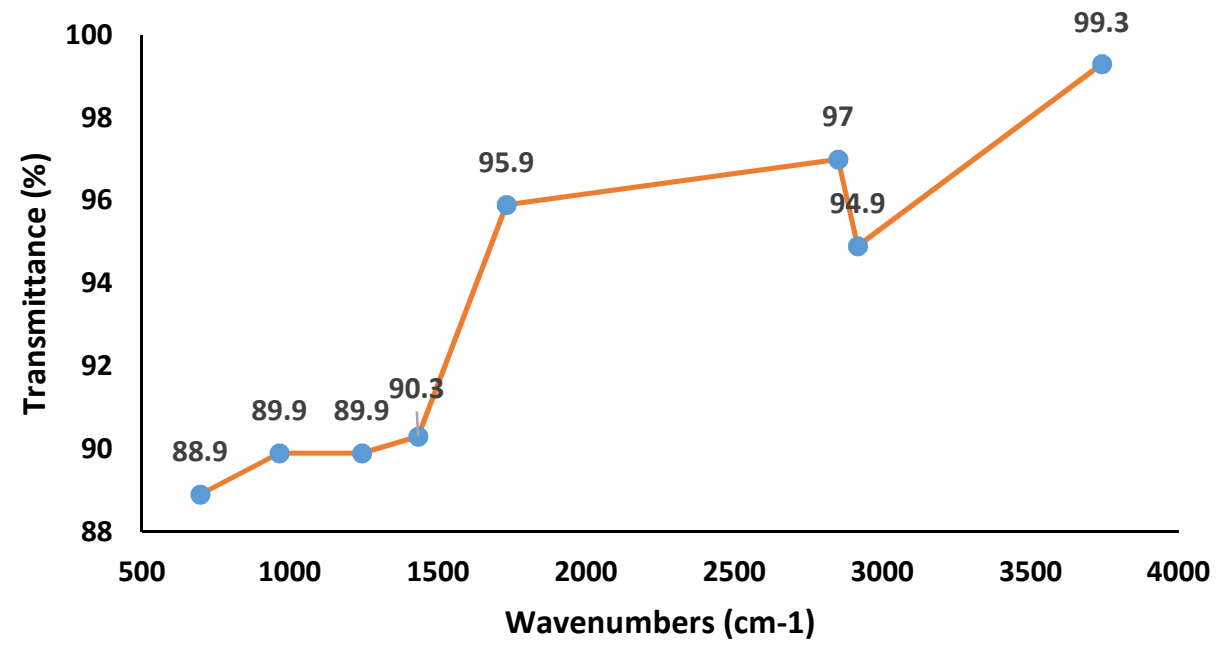

Gambar 13. Grafik panjang gelombang $115^{\circ} \mathrm{C}$

Berdasarkan gambar 13, grafik intensitas serapan gugus fungsi panjang gelombang pada material PVC menunjukkan panjang gelombang pada sample bagus dengan nilai gelombang $698.10 \mathrm{~cm}^{-1}-1731.24 \mathrm{~cm}^{-1}$ mengalami kenaikan panjang gelombang, mulai penurunn panjang gelombang pada nilai gelombang $2917.44 \mathrm{~cm}^{-1}$ dan setelah itu mengalami keniakan panjang gelombang sampai dengan nilai $3740.90 \mathrm{~cm}^{-1}$. 


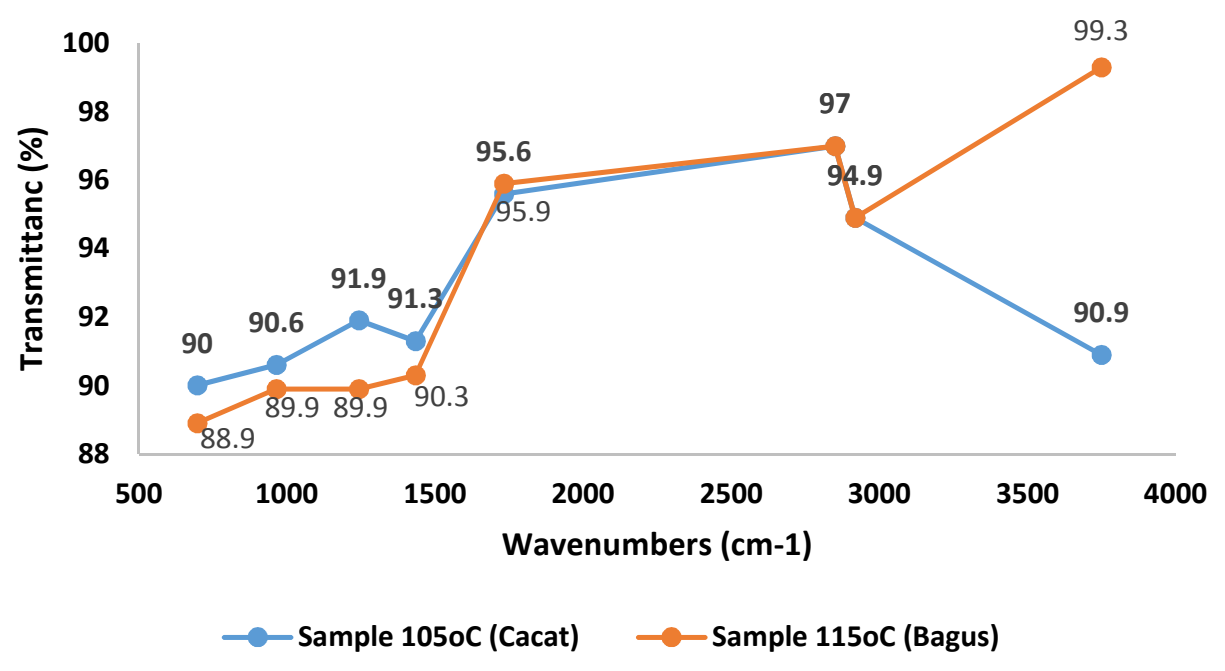

Gambar 14. Grafik perbedaan sample

Berdasarkan Gambar 14, intensitas serapan gugus fungsi pada material PVC hasil sample $105^{\circ} \mathrm{C}$ (cacat) dan sample $115^{\circ} \mathrm{C}$ (bagus) menunjukkan perbedaan panjang gelombang sebesar $8,4 \%$ panjang gelombang sample $105^{\circ} \mathrm{C}$ (cacat) dengan puncak gelombang puncak 90,9\% dengan nilai gelombang $3749.77 \mathrm{~cm}^{-1}$ mengalami penurunan pada akhir jika dilihat pada grafik dan sample $115^{\circ} \mathrm{C}$ (bagus) dengan puncak gelombang 99,3\% dengan nilai gelombang $3740.90 \mathrm{~cm}^{-1}$ mengalami kenaikan pada akhir gelombang jika dilihat pada grafik.

Pada spektrum hasil analisis FT -IR, menunjukkan $\mathrm{OH}$ tekuk pada nilai gelombang $3749.77 \mathrm{~cm}^{-1}$ dan $3740.90 \mathrm{~cm}^{-1}$. Sedangkan berdasarkan study sebelumnya (Susi Nurdayat, Tetty Kemala, Sudirman, dan Aloma karo karo 2004) menjelaskan bahwa pitapita serapan pada nilai gelombang $2962 \mathrm{~cm}^{-1}-2851 \mathrm{~cm}^{-1}$ merupakan vibrasi dari ulur $\mathrm{CH}$. Pada penelitian (Arum Yuniari, Emiliana Kasmujiastuti 2014) serapan C-H muncul pada nilai gelombang $2973 \mathrm{~cm}^{-1}-2816 \mathrm{~cm}^{-1}$ dan $2824 \mathrm{~cm}^{-1}$. Sedangkan vibrasi ulur CH PVC sample cacat ditemukan pada nilai gelombang $2918.19 \mathrm{~cm}^{-1}, 2917.34 \mathrm{~cm}^{-1}$. Apabila dibandingkan dengan PVC sample bagus vibrasi ulur CH ditemukan pada nilai gelombang $2850.53 \mathrm{~cm}^{-1}, 2850.314 \mathrm{~cm}^{-1}$. Sedangkan vibrasi CO sample PVC cacat terdapat pada nilai gelombang $1732.76 \mathrm{~cm}^{-1}$ dan sample PVC bagus vibrasi CO terdapat pada nilai gelombang $1731.24 \mathrm{~cm}^{-1}$. Sedangkan vibrasi tekuk CC terdapat pada nilai gelombang $1433.79 \mathrm{~cm}^{-1}$ dan $1243.31 \mathrm{~cm}^{-1}$ sample cacat dan ada pada nilai gelombang $1433.61 \mathrm{~cm}^{-1}$ dan 1243.40 $\mathrm{cm}^{-1}$ sample bagus. Spektrum vibrasi pada penelitian sample cacat CCI nilai gelombangnya $697.44 \mathrm{~cm}^{-1}$ dan CCI pada sample bagus dengan nilai gelombang $698.10 \mathrm{~cm}^{-1}$. 
Budiarto Djono Siswanto, Analisis pengaruh temperature terhadap sifat termal...

\section{KESIMPULAN}

Energi yang dilepas menunjukan semakin besar selisih temperatur heating, semakin besar energi yang dilepas. Energi paling besar dilepas adalah sebesar 1,938 Watt pada temperatur cooling $17^{\circ} \mathrm{C}$ dan heating $115^{\circ} \mathrm{C}$. Selanjutnya dapat dilihat selisih antara suhu heating $105^{\circ} \mathrm{C}$ dan $115^{\circ} \mathrm{C}$ sebesar 0,198 Watt. Energi panas yang di serap oleh air pendingin menunjukan semakin besar temperatur heating, semakin besar energi yang di serap. Energi di lepas sebesar 14,857 Watt pada temperatur cooling $17^{\circ} \mathrm{C}$ dan heating $115^{\circ} \mathrm{C}$. Semakin tinggi kenaikan temperatur, semakin tinggi energi yang dilepas air pendingin. Hasil pengujian DSC sample A.1 dan A.2 Hasil pengujian DSC sample A.1 dan A.2 menunjukkan bahwa temperatur leleh dari keduanya hampir sama yaitu sekitar $78^{\circ} \mathrm{C}$ tetapi terdapat perbedaan pada $\mathrm{T}_{\mathrm{g}}$ (temperature glass) sebesar $0,013 \mathrm{~J} / \mathrm{g}^{\circ} \mathrm{C}$ lebih cepat spesimen uji A.2 $115^{\circ} \mathrm{C}$. Hasil pengujian FTIR sample A.1 dan A.2 menunjukan adanya perbedaan panjang gelombang paling tinggi sampai dengan 8,4\% pada nilai gelombang $3749.77 \mathrm{~cm}^{-1}$ dan $3740.90 \mathrm{~cm}^{-1}$.

\section{UCAPAN TERIMAKASIH}

Kami Peneliti mengucapkan banyak terimakasih kepada Ketua Prodi Teknik Mesin dan hal-hal yang sangat membantu penelitian ini.

\section{REFERENSI}

[1] A. Akbarzadeh and M. Sadeghi, "Parameter Study in Plastic Injection Molding Process using Statistical Methods and IWO Algoritm," International Journal Modeling And Obtimization, vol. 1, no. 2, pp. 44-57, 2011.

[2] W. Chenetal, Packaging Pharmaceuticals Hand Book, New York: Informa, 2005.

[3] J. P. Holman, Heat Transfer, New York: Mc-Graw Hill, 2010.

[4] M. Y. Yuhazri, A. J. Zulfikar and A. Ginting, "Fiber Reinforced Polymer Composite as a Strengthening of Concrete Structures : A Review," in Materials Science and Engineering, Medan, 2020.

[5] A. J. Zulfikar, "The Flexural Strength of Artificial Laminate Composite Boards made from Banana Stems," Budapest International Research in Exact Sciences (BirEx) Journal, vol. 2, no. 3, pp. 334340, 2020.

[6] A. J. Zulfikar and M. Y. R. Siahaan, "Analisis Signifikansi Roda Skateboard Berbahan Komposit Serbuk Batang Pisang Terhadap Perfoma Kecepatan Dengan Metode Anova," Jurnal Rekayasa Material, Manufaktur dan Energi, vol. 4, no. 2, pp. 83-90, 2021.

[7] A. J. Zulfikar, A. Sofyan and M. Y. Siahaan, "Numerical Simulation on The Onion Dryer Frame Capacity of $5 \mathrm{~kg} /$ hour," JMEMME (Journal of Mechanical Engineering Manufactures Materials and Energy), vol. 2, no. 2, p. 86-92, 2018. 
[8] D. Antonius, S. D. Budiarto and B. P. Tito, "Analisis Laju Aliran Panas Proses Thermoforming Blister Packing Mesin Uhlmann UPS B1240 pada Material PVC," Jurnal METTEK, vol. 6, no. 1, pp. 2636, 2020 .

[9] F. P. Incropera and D. P. DeWitt, Fundamentals of Heat Transfer, New York: John Wiley \& Sons, Inc., 1996.

[10] M. D. Sebayang, S. Gideon and J. L. Panjaitan, "PENGARUH PERLAKUAN PANAS TERHADAP KABEL PVC," Majalah Polimer Indonesia, vol. 18, no. 1, pp. 9-13, 2015.

[11] K. Bordonaro, "STUDI PENGARUH PARAMETER PROSES TERHADAP KUALITAS PRODUK," Petra, vol. 4, no. 2, pp. 50-62, 2008.

[12] G. M. Artama, , Proses Injection Molding Cycle Pada Injection Molding Machine dan Molding Defect, Yogyakarta: Universitas Gadjah Mada Press, 2004.

[13] M. D. Sebayang, "The microstructure of the radiation effect of the heat on the complete cable NYM," Perhimpunan Polimer Indonesia (HPI), vol. 3, no. 1, pp. 34-41, 2016.

[14] C. Anam, K. S. Firdausi and S. Sirojudin, "ANALISIS GUGUS FUNGSI PADA SAMPEL UJI, BENSIN DAN SPIRITUS MENGGUNAKAN METODE SPEKTROSKOPI FTIR," QC Physics, vol. 1o, no. 1, pp. 79-85, 2009.

[15] A. Todingbua, R. Thahir, I. Saka, M. Dase and P. Pabbenteng, "SINTESIS DAN KARAKTERISASI POLIELEKTROLIT KOMPLEKS (PEC) KITOSAN-PEKTIN SEBAGAI MATRIKS FILM INDIKATOR PH," in SEMINAR NASIONAL HASIL PENELITIAN 2018, Makassar, 2018. 